\title{
Analysis of adoption of sustainable land management practices for yam production in Osun State, Nigeria
}

\author{
Aminu F. O. *, Rosulu H. O., Balogun E. O. S., and Babawale O. H. \\ Department of Agricultural Technology, School of Technology, Yaba College of Technology, Epe Campus, P. M. B. \\ 2011, Yaba, Lagos State, Nigeria. \\ Corresponding author. Email: folaafe02@gmail.com; Tel: +2348036027236.
}

Copyright @ 2018 Aminu et al. This article remains permanently open access under the terms of the Creative Commons Attribution License 4.0, which permits unrestricted use, distribution, and reproduction in any medium, provided the original work is properly cited.

Received 30th November, 2018; Accepted 22nd December, 2018

\begin{abstract}
The study investigated the adoption of sustainable land management practices (SLMP) for yam production in Osun State, Nigeria. Primary data were collected from 120 yam farmers with the aid of questionnaire through a multistage sampling procedure. The SLMP studied included structural and mechanical erosion control practices (SMECP), agronomic practices (AP), soil management practices (SMP) and cultivation practices (CP). Data were analysed using descriptive statistics and multivariate probit model. Results revealed that contour bund adopted by $25.5 \%$ of the farmers was the only SMECP employed in the study area. The major Ap adopted by farmers were mulching (59.2\%), multiple cropping (22.9\%), cover cropping (34.2\%), and crop rotation (38.3\%). Application of inorganic fertilizer (62.6\%), compost $(23.3 \%)$, farmyard manure (25\%), bush fallowing (21.7\%) and shifting cultivation (20.8\%) were the most used SMP while minimum tillage $(31.7 \%)$ was the only CP adopted in the study area. Educational level of farmers, farm size, labour availability, membership of cooperative associations and extension contacts were some of the socio-economic factors influencing the adoption of SLMP in the study area. It is recommended that strategies to improve educational level of the farmers and create awareness about sustainable land management practices should be reinforced in the study area.
\end{abstract}

Keywords: Adoption, multivariate probit model, Socio-economic factors, sustainable land management practices.

\section{INTRODUCTION}

Land is a major factor in agriculture. Its degradation is a worldwide issue and an extraordinary challenge to sustaining the natural, economic and social services given by different ecosystem (Motavali and Bardhan, 2013). The contrary effects of land debasement subvert individual's sustenance, economic well-being, and health status of billions of people in developing countries (Global Environmental Facility, 2003). According to Titilola et al. (1990), some communities in Nigeria have had over $10 \%$ of their land mass diminished by erosion and still stand the chance of losing a greater amount of their cultivable land in the closest future. In Africa, about 28 percent of the land is degraded and this costs the continent an estimated 56 billion euros annually (Joachim, 2016). Populace weight, deforestation, steep slopes, poor cultivation strategies and vulnerable soils are the real reasons for disintegration
(Mugisha and Alobo, 2012).

TerrAfrica (2005) defines SLM as "the adoption of land use systems that enable land users to maximize the economic and social benefits from the land through suitable management practices while maintaining the ecological support functions of the land resources. FAO (2009) in Babalola and Olayemi (2013) defined SLMP as "the acceptance of land use frameworks that, through proper management practices, enables land users to optimize the economic and social advantages from the land while keeping up or upgrading the bionomical support functions of the land assets". The objective of land management is to secure the land and improve its execution, to cultivate gainfully and protect natural quality for a considerable length of time. They include conventional tillage system, organic manure, mixed farming, 
crop rotation and mulching. This connotes that the management of agricultural lands would conserve the lands productivity in an environmentally, economically and socially sustainable way (Oloyede et al., 2014).

Mugisha and Alobo (2012) reported that, the demographic characteristics influencing the choice of land management practices were farmer's age, household size and education level; and plot level characteristics such as slope gradient and crop types. Babalola and Olayemi (2013) found that farmers' level of education and their participation in community based organisations positively influenced their adoption of the SLMP.

Yam (Dioscorea spp) is a soil loving crop which requires a good land management practices to attain the quality and quantity expected by the farmer at the end of the planting season. Yam is a tropical crop in the genus Dioscorea. According to FAO (1988), Nigeria produced 18.3 million tonnes of yam from 1.5 million hectares of farm land representing $73.8 \%$ of total yam production in Africa. This increased to 35.017 million metric tonnes with value equivalent to US\$5.654 billion in 2008. International Institute of Tropical Agriculture reported that about 70 percent of the world yam production amounting to 17 million tonnes was produced in Nigeria from 2,837,000 hectares of land area (Hahn et al., 1993). There are up to 600 species but the most economical in Nigeria are; Dioscorea rotundata (white yam), Dioscorea cayenensis (yellow yam) and Dioscorea alata (water yam). The cultivation of yam complements food security. Yam is a major source of calories for millions of the tropical and subtropical populations and provides some nutritional benefits in the form of protein and micronutrients. Yam production is constrained in Nigeria by many factors, such as: unavailability of planting materials, land degradation, low and declining soil fertility, poor storage facilities as well as pests and diseases (Ibitoye and Attah, 2012). These obstacles undermine food production and farmers' ability to generate sustainable incomes. Farmers have been exposed to various land management practices such as contour ploughing, terracing, mulching, minimum tillage, among others. These practices have been tried on homesteads and affirmed successful. Nonetheless, not all farmers are applying them regardless of the acknowledgment that their farmland is getting progressively degraded (Mugisha and Alobo, 2012). This study therefore aimed to identify the various land management practices adopted by the yam farmers and analyse the factors influencing the adoption of land management practices in the study area.

\section{METHODOLOGY}

\section{Study area}

This study was conducted in llesa West Local Government Area of Osun state, Nigeria. The headquarter is in the town of Oja Oba (Ereja Square) on the outskirt of the city of llesa. It is located on coordinates $7^{\circ} 39^{\prime} \mathrm{N}$ and $4^{\circ} 43^{\prime} \mathrm{E}$. It has an area of $63 \mathrm{~km}^{2}(24 \mathrm{sqm})$ and a population of 103,555 at the 2006 census. The major occupation of the people in the area is farming. Crops cultivated include maize, yam, cassava, cocoyam, cocoa, kolanut, citrus and vegetables. Livestock like sheep, cattle, pig, goat, rabbit and poultry are additionally raised for sales and consumption.

\section{Sampling procedures}

Primary data was collected through interview schedule with the aid of questionnaire. The questionnaire sought for information on socio-economic characteristics of respondents, various land management practices and challenges of adopting the various LMP.

Multistage sampling technique was used to select the respondents for this study. First stage involved the purposive selection of two zones out of the three zones in the study area due to the presence of large yam farmers. The second stage was the random selection of two villages each from the two selected zones making a total of four villages. In the third stage, simple random sampling techniques was employed to select two communities from each of the villages making a total of 8 communities while the last stage involved the random selection of 15 households from the selected communities making a total of 120 respondents.

\section{Analytical techniques}

The following analytical tools were employed in the analysis;

\section{Descriptive analysis}

Descriptive statistics such as frequencies, percentages, means and standard deviation was adopted to describe information on the socio-economic characteristics of the yam farmers as well as the SLMP used by the farmers in the study area.

\section{Multivariate Probit (MVP) Model}

The MVP model was used to analyse the factors influencing the adoption of sustainable land management practices in the study area. A multivariate probit has been used previously in a number of adoption studies (Otieno et al., 2011; Timu et al., 2013). The multivariate probit is an extension of the probit model (Greene, 2003) and is used to estimate several correlated binary outcomes jointly. In a single-equation statistical model, information on a farmer's 
adoption of one SLMP does not alter the likelihood of adopting another. The MVP approach simultaneously models the influence of the set of explanatory variables on each of the different practices while allowing for the potential correlation between unobserved disturbances as well as the relationship between the adoptions of different land management practices (Belderbos et al., 2004). One source of correlation may be complementarity (positive correlation) and substitutability (negative correlation) between different practice. Failure to capture unobserved factors and interrelationships among adoption decisions regarding different practices will lead to bias and inefficient estimates (Greene, 2008). Consider the i farm household $(I=1, \ldots, M)$ which is facing a decision on whether or not to adopt the available LMP on plot $(j=1, \ldots, j)$. Let $U_{0}$ represent the effects to the farmer from traditional management practices, and $U_{k}$ represent the benefit of adopting the $k^{\text {th }}$ LMP. According to Sheng (1989) and Babalola and Olayemi (2013), these land management practices are classified as follows:

1. Structural and Mechanical Erosion Control Practices (SMECP) which include contour bund and construction of ridges across the slope.

2. Agronomic Practices (AP) which include multiple cropping, mulching, and crop rotation.

3. Soil Management Practices (SMP) which includes compost and farm manure.

4. Cultivation Practices (CP) which includes minimum tillage.

The general multivariate probit model is specified as follows:

$\mathrm{Y}_{\mathrm{ijk}}^{*}=\mathrm{X}_{\mathrm{ij}}^{\prime} \beta_{\mathrm{k}}+\mathrm{U}_{\mathrm{ij}}(k=S M E C P, A P, S M P, C P)$

Using the indicator function, the unobserved preferences in equation (1) translate into the observed binary outcome equation for each symptom as follow:

$Y_{k}=\left\{\begin{array}{l}1 \text { if } Y_{i j k}^{*}>0 \\ 0 \text { otherwise }\end{array}\right\}(k=S M E C P, A P, S M P, C P) \ldots \ldots .$.

It is important to note that, a farmer is regarded as an adopter of a practice or technology if he/she used it for at least a planting season (Afolami et al., 2015).

The model used to estimate the factors that influence farmers' choice of land management practices is specified as follows;

$y=\alpha+\beta 1 \times 1+\beta 2 \times 2+\ldots+\beta 11 \times 11+e$

Where; $Y=$ Land management practices (SMECP, AP, $S M P, C P$ ), $\mathrm{X}_{1}=$ Age of farmers (years), $\mathrm{X}_{2}=\mathrm{Sex}$ ( 1 if male, 0 otherwise), $X_{3}=$ Educational level (at least a primary school education $=1$, otherwise $=0), X_{4}=$ Farm size, (hectares), $X_{5}=$ Type of labour used, $X_{6}=$ Farming experience in years, $X_{7}=$ Membership of farmers' cooperative society (yes $=1,0=$ otherwise), $X_{8}=$ Access to extension services (yes $=1,0=$ otherwise), $X_{9}=$ Household Size (No of people), $X_{10}=$ Access to loan (yes $=1,0=$ otherwise), $X_{11}=$ Income $(\$)$, e is the random error term, and $\beta 1$ to $\beta 11$ are the coefficients to be estimated.

\section{RESULTS AND DISCUSSION}

The result (Table 1 ) reveals that the mean age of the farmers was 51 years. This indicates that the yam farmers in the study area were getting old and has implication on physical ability to work, efficient utilization of resources as well as ability to adopt innovation in the study area. This result validates the findings of Odoemelam and Ajuka (2015) that older people were involved in indigenous farm management practices than younger ones in South-east agro-ecological zone of Nigeria. The mean year of schooling of about 9 years depicts that majority of the farmers had primary education. The result agrees with Babalola and Olayemi (2013), who reported that, the proficiency level among farmers in Ogun State is still generally low, with a dominant part of them having less than secondary school education. Result also shows that the mean household size of the sampled yam farmers was six people. This implies that the yam farmers had small household size and could impact negatively on family labour availability in the study area. The mean farming experience of about 11 years reveals that the yam farmers had considerable years of experience in yam production as well as better understanding of the various land management practices adopted by them. Furthermore, the average farm size of $1.2 \mathrm{ha}$ implies that the farmers were small scale farmers. This has implication for yield level and income accruable to the yam farmers.

\section{Land management practices adopted by the yam farmers in the study area}

Figure 1 presents the result on the various SLMP adopted by yam farmers in the study area. The result reveals that $25.5 \%$ of the farmers adopted contour bund as their structural and mechanical erosion control practices. This implies a poor use of SMECP in the study area. This finding is in consonance with Aromolaran (1998) and Babalola and Olayemi (2013) who attributed the poor utilisation of SMECP in their study areas to its associated costs, which are often beyond the farmers' capacity. Majority (59.2\%) of the yam farmers adopted mulching as their agronomic practices. Other AP employed by the yam farmers were multiple cropping $(22.9 \%)$, cover cropping $(34.2 \%)$, and crop rotation (38.3\%). Application of inorganic fertilizer $(62.6 \%)$ was the most used soil 
Table 1. Summary statistics of some of the socio-economic variables $(N=120)$.

\begin{tabular}{lcccc}
\hline Variable & Minimum & Maximum & Mean & Std. Deviation \\
\hline Age & 27 & 71 & 51.43 & 10.739 \\
Education & 0 & 18 & 8.9 & 2.774 \\
Household size & 1 & 17 & 6 & 2.792 \\
Farming experience & 1 & 37 & 10.97 & 7.120 \\
Farm size & 0.1 & 6 & 1.2 & 1.0855 \\
Farm income & 28,000 & $2,250,000$ & $423,679.72$ & 40491.640 \\
\hline
\end{tabular}

Source: Field survey data, 2017.

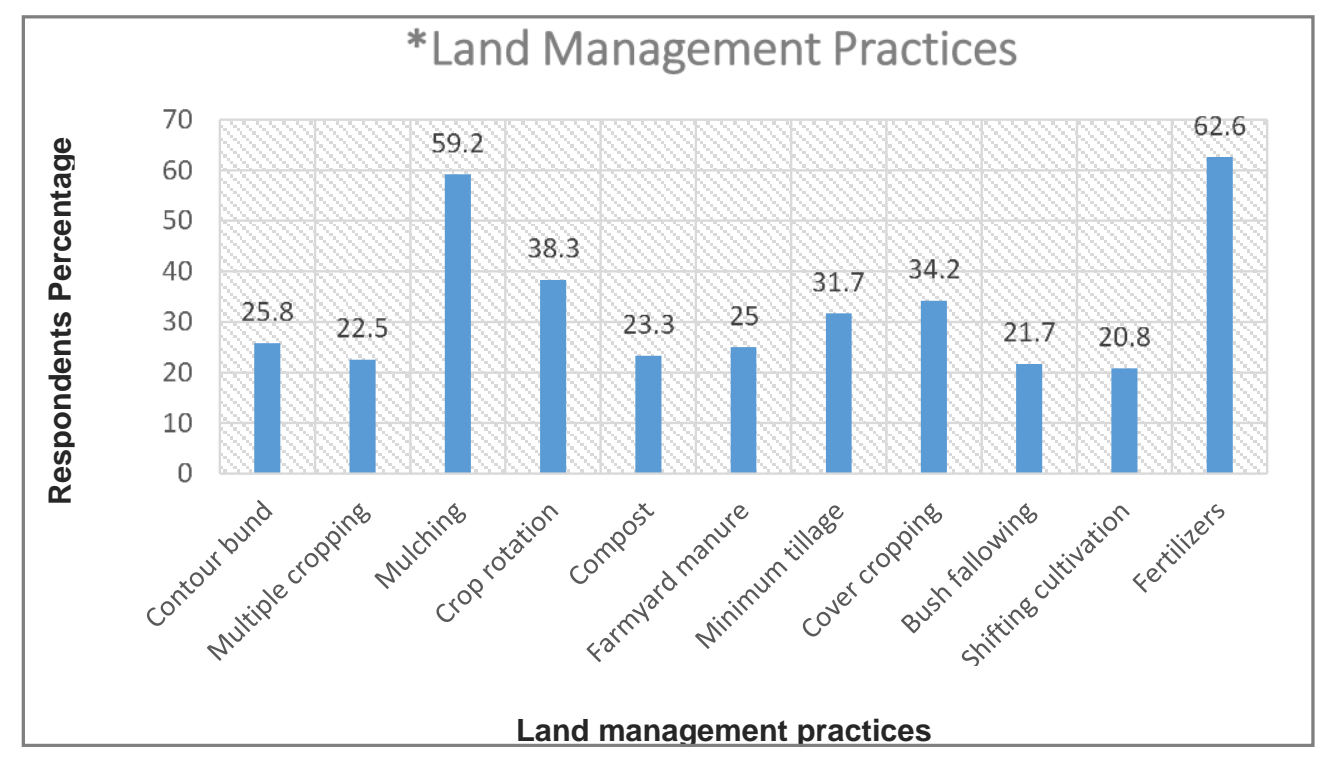

Figure 1. Land management practices adopted by respondents in the study area. *Multiple responses. Source: Field survey data, 2017.

management practices in the study area. This may be unconnected to the productivity potential of fertilizer use on crops. Aromolaran, (1998), however submitted that, the high utilization of inorganic manures may not be purposely focused at soil protection and that the preservation impact on the soil is because of the rapid growth in vegetation from fertilizer application. Other SMP adopted by the respondents were compost (23.3\%), farmyard manure (25\%), bush fallowing $(21.7 \%)$ and shifting cultivation (20.8\%). Minimum tillage (31.7\%) which involves low disruption of the soil during cultivation was the only cultivation practices (CP) used by the yam farmers in the study area.

\section{Determinants of sustainable land management practices adopted by yam farmers in the study area}

The Wald test results of the correlation of one SLMP with another SLMP is presented in Table 2. The multivariate probit regression model is highly significant overall as the Wald test statistic is significant at $1 \%$. The likelihood ratio test of rho $(\rho)$ statistically significant $($ at $p<0.01)$ indicates that the model has a good fit in modeling factors that influence adoption of SLMP in the study area. Rho refers to the correlation coefficient among the error terms of the adopted SLMP. Rho21, for instance, is the correlation coefficient among the error terms of SMECP (1) and AP (2). The correlation coefficients among the error terms are also significant showing that the various SLMP are interdependent. Some of the SLMP are complementary (positive significant correlation coefficients), while others are substitutes/compete (negative significant correlation coefficients).

\section{Multivariate probit results on adoption of SLMP}

Results of the MVP regression models used to examine the determinants of the four SLMP adopted by the yam farmers are presented in Table 3. 
Table 2. Results of the Wald test of joint decision to adopt different LMP.

\begin{tabular}{lccc}
\hline Correlation among SLMP & Correlation Coefficients & Robust Std. Error & P-value \\
\hline rho21 & 0.709 & 0.215 & 0.000 \\
rho31 & 0.218 & 0.032 & 0.022 \\
rho41 & -0.021 & 0.067 & 0.835 \\
rho32 & 0.119 & 0.022 & 0.231 \\
rho42 & -0.005 & 0.141 & 0.967 \\
rho43 & 0.086 & 0.019 & 0.367 \\
\hline
\end{tabular}

Table of p-values of farmers' decisions to adopt different LMP where 1=SMECP, 2=AP, 3=SMP and 4=CP.

Table 3. Factors influencing adoption of land management practices in the study area.

\begin{tabular}{|c|c|c|c|c|}
\hline Variable & SMECP & AP & SMP & $\mathbf{C P}$ \\
\hline Age (years) & $0.021(0.467)$ & $-0.088(0.022)$ & $0.010^{* \star *}(0.000)$ & $-0.78^{* * *}(-4.13)$ \\
\hline Sex (dummy) & $20.447^{\star \star \star}(0.000)$ & $4.213^{\star \star \star}(3.088)$ & $0.956(0.056)$ & $0.075(0.004)$ \\
\hline Education (years) & $0.409^{\star \star \star}(3.396)$ & $0.292(0.590)$ & $-0.169(0.851)$ & $0.351^{* *}(2.027)$ \\
\hline Farm size (ha) & $0.909^{\star *}(2.113)$ & $-1.78^{\star \star \star}(2.971)$ & $0.061(0.012)$ & $-1.195^{\star * *}(3.38)$ \\
\hline Labour & $0.029(0.006)$ & $-0.05^{\star * *}(-0.00)$ & $0.132^{\star \star}(2.15)$ & $0.154(0.637)$ \\
\hline Experience (years) & $0.023(0.231)$ & $0.027(0.060)$ & $-0.004(0.010)$ & $0.005(0.012)$ \\
\hline Cooperative membership (dummy) & $0.365(0.892)$ & $0.847(0.519)$ & $0.38^{* *}(2.074)$ & $0.472^{* \star}(2.28)$ \\
\hline Extension contact (dummy) & $-0.365(-0.560)$ & $0.203(0.058)$ & $0.959^{\star \star \star}(4.757)$ & $-0.302(-0.191)$ \\
\hline Household size (No of people) & $0.015(0.018)$ & $0.378^{\star \star \star}(2.567)$ & $0.085(0.748)$ & $0.022(0.048)$ \\
\hline Loan access (dummy) & $0.600(0.975)$ & $1.941(0.016)$ & $0.630^{* *}(2.311)$ & $0.108(0.033)$ \\
\hline Income (\#) & $0.000 * *(2.266)$ & $0.000(0.651)$ & $0.112^{\star *}(2.093)$ & $0.004(1.529)$ \\
\hline Constant & $-24.113^{\star \star}(-2.03)$ & $-3.63^{\star \star \star}(-2.87)$ & $-0.941^{* * *}(-3.2)$ & $-2.68^{* *}(-2.005)$ \\
\hline
\end{tabular}

$\mathrm{N}=119$; Log pseudo likelihood $=-247.40$; Wald chi2 $(16)=115.02$; Prob. $>$ chi2 $=0.0000{ }^{* \star *}$ and ${ }^{\star *}$ indicate significance at $1 \%$ and $5 \%$ levels respectively. Figures in parentheses are $z$-values.

Source: Computed from Field Survey Data, 2017.

\section{Structural and mechanical erosion control practices (SMECP)}

Results indicate that the probability of adopting structural and mechanical erosion control practices as a land management practice by farmer in the study area was significantly influenced by sex of farmer $(p<0.01)$, education $(p<0.01)$, farm size $(p<0.05)$ and income $(p<0.05)$.

Sex of the farmers had positive significant relationship with adoption of SMECP at $1 \%$ alpha level. This implies that male farmers are more likely to adopt SMECP such as contour bund, as SLMP than female farmers in the study area. Farmers educational level positively and significantly $(p<0.01)$ influenced the use of SMECP in the study area. This agrees with the findings of Babalola and Olayemi, (2013) that, the choice to utilize SMECP to preserve soil against land degradation problem increase with educational level of the farmers. Nkonya et al. (2008) reported that primary, secondary and post-secondary education were associated with increased use of land management practices in Uganda.
The size of land cultivated by the farmers was also positive and significant $(p<0.05)$. This suggests that the larger the farm size the more likely the adoption SMECP in the study area. Furthermore, income of the farmer had positive significant influence on adoption of SMECP in the study area. This proposes that farmers with high income employed the use SMECP more than the low income farmers. This could be due to lack of fund of farmers as affirmed by the findings of Aromolaran (1998) and Babalola and Olayemi (2013).

\section{Agronomic practices}

Results in Table 3 also reveals that sex $(p<0.01)$ and household size $(p<0.01)$ had positive significant relationship while farm size $(p<0.01)$ and labour $(p<0.01)$ had negative significant relationship with agronomic practices in the study area.

This result implies that male farmers with large household size, small farm size and hires few labour adopted the use of AP such as mulching, multiple cropping, cover 
cropping and crop rotation in the study area. The positive influence of household size implies availability of family labour. The negative influence of farm size corroborates the findings of Awoyinka et al., (2009), Babalola and Olayemi (2013) and Oloyede et al. (2014) that adopters of AP were those with small farm holdings.

\section{Soil management practices}

Age $(p<0.01)$, labour $(p<0.05)$, cooperative membership $(p<0.05)$, extension contact $(p<0.01)$, loan access $(p<0.01)$ and income $(p<0.05)$ were the socio-economic factors influencing the adoption of Soil Management Practices such as inorganic fertilizer, compost, farmyard manure, bush fallowing and shifting cultivation as SLMP by the yam farmers in the study area.

The positive significant influence of these variables on SMP indicate that older farmers who hires people to work on their farms, who is a member of cooperative society, had contact and trained by extension agents, had access to loan and earned high income adopted the use of SMP in the study area. The positive influence of labour according to Oloyede et al. (2014) implies that labour availability increases the farmers' likelihood of utilizing fertilizer as SMP. The result on extension contacts however contradicts the findings of Oloyede et al. (2014) who reported in similar study that farmers contacts with extension agents reduce the probability of farmers using crop rotation, cover cropping and bush fallow.

\section{Cultivation practices}

Results in Table 3 further reveals that the adoption of cultivation practices (CP) such as minimum tillage was positively influenced by educational level of farmers $(p<0.01)$ and membership of cooperative association $(p<0.05)$ and negatively influenced by age of farmers $(p<0.01)$ and their farm size $(p<0.01)$. These imply that educated younger farmer who belonged to cooperative association and cultivated small farm land adopted CP in the study area. This result is in agreement with the findings of Aminu and Hassan (2016) that younger farmers are better adopters and more receptive of innovation than older farmers.

\section{Conclusion and recommendations}

Findings from the study revealed that the yam farmers were knowledgeable about the various sustainable land management practices in the study area. Educational level of farmers, farm size, labour availability, membership of cooperative associations and extension contacts were some of the factors influencing the adoption of these
SLMPs in the study area. It is therefore recommended that strategies to improve the educational level of the farmers such as adult education and seminars should be strengthened to provide information and awareness about sustainable land management practices as a whole. Farmers should be encouraged to form and join viable cooperative societies (farmers' organisations) to speed up the rate of adoption of SLMP since they are more likely to be aware of government programmes on SLMP. In addition, the frequency of visits of extension agents should be increased and practical programmes to improve awareness on land management practices such as workshops, on-farm demonstrations and trainings should be promoted.

\section{CONFLICT OF INTEREST}

The authors declare that they have no conflict of interest.

\section{REFERENCES}

Afolami, C. A., Obayelu, A. E., \& Vaughan, I. I. (2015). Welfare impact of adoption of improved cassava varieties by rural households in South Western Nigeria. Agricultural and Food Economics, 3,18.

Aminu, F. O., \& Hassan, T. I. (2016). Climate change and arable crop production: A Case of Epe Local Government Area of Lagos State, Nigeria. In Onigemo, M. A., Bolarinwa, J. B., Godonu, K. G., Jaji, M. F. O., Asafa, A. R., \& Okeowo, T. A, (Eds.). Revamping Nigerian Agriculture through Public-Private Sector Synergy. Proceedings of 2nd International Conference of School of Agriculture, Lagos State Polytechnic, held at Lagos State Polytechnic, Ikorodu, Lagos State, Nigeria. 18th21st April, 2016. Pp. 103-112

Aromolaran, A. B. (1998). Economics analysis of soil conservation practices in South Western Nigeria. Eleventh Series of Issues in African Rural Development Monograph, Pp. 1-28.

Awoyinka, Y. A., Akinwumi, J. A., Okoruwa, V. O., \& Oni, O. A. (2009). Effects of livelihood strategies and sustainable land management practices on food crop production efficiency in South-West Nigeria. Agricultural Journal, 4(3),135-143

Babalola, D. A., \& Olayemi, J. K. (2013). Determinants of farmers' preference for sustainable land management practices for maize and cassava production in Ogun State, Nigeria. Fourth International Conference of the African Association of Agricultural Economists, 22-25 September, Hammamet, Tunisia.

Belderbos, R., Carree, M., Diederen, B., Lokshin, B., \& Veugelers, R. (2004). Heterogeneity in R\&D cooperation strategies. International Journal of Industrial Organization, 22(8-9), 1237-1263.

FAO (1988). Production Year Book. FAO ROME, Vol.43.

FAO (2009). Country Support Tool - for Scaling-Up Sustainable Land Management in Sub-Saharan Africa. Food and Agriculture Organization of the United Nations, Rome, Italy.

Global Environmental Facility (2003). Operational program 15 on sustainable land management.

Greene, W. H. (2003). Econometric Analysis, 2nd Edition, New 
York, Macmillan.

Greene, W. H. (2008). Econometric Analysis. 6th (International) ed. Upper Saddle River, N.J., USA: Prentice-Hall, Inc.

Hahn, S. K., Osiru D. S. O., Akoroda, M. O., Atoo, J. A. (1993). Production of yams, present role and future prospects. IITA Research Guide 46, IITA Ibadan, 36p.

Ibitoye, S. J., \& Attah, S. (2012). An assessment of yam mini-sett utilization and profit level in Kogi State, Nigeria. Int. J. Applies Res. Technol. (IJART), 1(5), 8-14.

Joachim, V. B. (2016). Alarm over land degradation in Africa. Bonn's Center for Development Research. https://www.dw.com/en/alarm-over-land-degradation-inafrica/a-19044890. Assessed on 18th December, 2018

Motavali, P., \& Bardhan, S. (2013). Global achievements in sustainable land management. International Soil and Water Conservation Research, 1(1), 1-10.

Mugisha, J., \& Alobo, S. (2012). Determinants of land management practices in the agricultural highlands of Uganda: A case of Kabale highlands in Western Uganda. Third RUFORUM Biennial Conference, 24-28 September 2012, Entebbe, Uganda.

Nkonya, E., Pender, J., Kayuki, C. K., Kato, E., Mugarura, S., Ssali, H., \& Muwonge, J. (2008). Linkages between land management, land degradation, and poverty in Sub-Saharan Africa: The Case of Uganda. Research Report 159, IFPRI: Washington, D.C.

Odoemelam, L. E., \& Ajuka, P. N. (2015). Indigenous farm management practices among rural farmers: Implications for sustainable environment in South-East Agro-Ecological Zone, Nigeria. Discourse Journal of Agriculture and Food Sciences, 3(1), 7-14.
Oloyede, A. O., Muhammad-Lawal, A., Ayinde, O. E., \& Omotesho, K. F. (2014). Analysis of soil management practices in cereal based production systems among smallscale farmers in Kwara State. Agro-Science, 14(2), 18-23.

Otieno, Z., Okello, J., Nyikal, R., Mwang' Ombe, A., \& Clavel, D. (2011). The role of varietal traits in the adoption of improved dryland crop varieties: The case of pigeon pea in Kenya. Afr. J. Agric. Res., 6(2), 176-193.

Sheng, T. C. (1989). Soil conservation for small farmers in the humid tropics. FAO Soil Bulletin Number 60 FAO Rome.

TerrAfrica (2005). Sustainable land management. www.fao.org/land-water/land.

Timu, A. G., Mulwa, R., Okello, J., \& Kamau, M. (2013). The role of varietal attributes on adoption of improved seed varieties. The case of sorghum in kenya. Paper presented at the 4th International Conference of the African Association of Agricultural Economists, September 22-25, 2013, Hammamet, Tunisia.

Titilola, S. O., Akande, S. O., Olomola, A., \& Akpokodje, G. (1990). Population pressure and environmental degradation: a pilot survey of economic effects of soil erosion in Efon-Alaye. In: Population-Environment interaction in Nigeria. Phillips, A. O., \& Ajakaiye, D. O. (eds.). The Nigeria Institute of Social and Economic Research (NISER) Ibadan, Nigeria. 